\title{
ОСОБЛИВОСТІ ОКСИДАТИВНИХ ПРОЦЕСІВ ПРИ ЕКСПЕРИМЕНТАЛЬНІЙ МЕХАНІЧНІЙ НЕПРОНИКНІЙ ТРАВМІ РОГІВКИ
}

Вступ. Дезорганізація процесів пероксидного окиснення має важливе значення в патогенезі механічної непроникної травми рогівки, однак ці взаємозв'язки вивчено недостатньо, що спонукало нас провести дослідження власне такого напрямку.

Мета дослідження - вивчити зміни інтенсивності пероксидного окиснення ліпідів, білків та вміст метаболітів нітрогену монооксиду в крові кролів за умов механічної непроникної травми рогівки в динаміці.

Методи дослідження. Експериментальні дослідження проводили на статевозрілих кролях породи "Шиншила". Для вивчення особливостей вільнорадикального окиснення при експериментальній механічній непроникній травмі ока спектрофотометрично в крові визначали концентрацію гідропероксидів, вміст ТБК-реактантів, ступінь окиснювальної модифрікації білків, рівень метаболітів нітрогену монооксиду.

Результати й обговорення. Встановлено підвищення вмісту продуктів білкової і ліпідної пероксидації в крові кролів за умови механічної непроникної травми рогівки. Результати нашого дослідження свідчать про хвилеподібну динаміку змін кінцевих продуктів нітрогену монооксиду в сироватці крові тварин при механічній непроникній травмі рогівки.

Висновки. За умови експериментальної непроникної травми рогівки спостерігають достовірне зростання у крові показників пероксидного окиснення ліпідів (підвищення рівнів гідропероксидів $і$ ТБК-активних продуктів) та окиснювальної модифрікації білків (альдегідо- і кетонопохідних динітрофенілгідразонів нейтрального й основного характеру) стосовно контролю з мінімальними значеннями на 7 добу та максимальними - на 14 добу $(p<0,05)$. Експериментальна непроникна травма рогівки супроводжується зниженням рівня кінцевих продуктів нітрогену монооксиду на 3-7 доби в середньому на 26,0 \% з наступним зростанням на 10 і 14 доби, відповідно, на 8,0 та 24,9 \% відносно контрольної групи $(p<0,01)$.

КЛЮЧОВІ СЛОВА: травма рогівки; оксидативний стрес; динаміка; експеримент.

ВСТУП. Травми ока у всьому світі становлять значну частину офртальмологічної практики [1]. У США щодня буває приблизно 2000 травматичних випадків, які потребують допомоги офтальмолога [2]. Розповсюдженість очної травми вивчено також у Великій Британії, Швеції, Греції та інших країнах [3]. Згідно з даними Н. А. Чуднявцева і співавт., поширеність травм органа зору в Україні в середньому становить 24,5 випадку на 10 тис. населення, при цьому патологія рогівки входить до трійки основних чинників втрати зору, частка якої становить 6,6-39,3 \% [4].

Епідеміологічні дані вказують на те, що більшість усіх травм очей отримують чоловіки віком 20-34 роки, які працюють насамперед у виробництві, будівництві, сільському господарстві, металургії [5-7]. Важливим також $є$ той факт, що

(с) С. В. Нестерук, І. М. Кліщ, 2018. ситуаційні фрактори, як, наприклад, виконання незнайомих завдань, використання несправного обладнання, погана організація робочого місця, теж підвищують ризик виникнення травм очей [6]. Найбільш поширеними травмами очного яблука є стороннє тіло рогівки, абразія рогівки, опіки хімічними речовинами і тупа травма $[7,8]$. При цьому першим кроком до розробки профрілактичних заходів для запобігання травмам ока $€$ розуміння етіології і механізмів ушкоджувального впливу [1].

До універсальних показників стійкості організму, його адаптивного потенціалу та переходу в патологічний процес належить порушення балансу між прооксидантно-антиоксидантною системою, що зумовлює мембранодеструктивні зміни внаслідок активації вільнорадикального окиснення ліпідів, білків та нуклеїнових кислот 
[9, 10]. Дезорганізація процесів пероксидного окиснення має важливе значення в патогенез механічної непроникної травми рогівки [11], однак ці взаємозв'язки вивчено недостатньо, що спонукало нас провести дослідження власне такого напрямку.

Мета дослідження - вивчити зміни інтенсивності пероксидного окиснення ліпідів, білків та вміст метаболітів нітрогену монооксиду в крові кролів за умов механічної непроникної травми рогівки в динаміці.

МЕТОДИ ДОСЛІДЖЕННЯ. Експериментальні дослідження проводили на статевозрілих кролях породи “Шиншила" масою від 2,5 до 3,0 кг згідно з Женевською конвенцією "International Guiding principles for Biochemical research involving animals" (Женева, 1990) та Загальними принципами експериментів на тваринах, схваленими на Національному конгресі з біоетики (Київ, 2001). Тварини отримували повноцінне збалансоване харчування і перебували в належних санітарно-гігієнічних умовах віварію Тернопільського державного медичного університету імені І. Я. Горбачевського.

Тварин поділили на контрольну групу - інтактні тварини (6 кролів) та дослідні групи - непроникне поранення рогівки, термін спостереження - 3 (1-ша група), 7 (2-га група), 10 (3-тя група) та 14 (4-та група) діб після отримання травми (54 кролі).

Експериментальну модель ушкодження рогівки відтворювали на обох очах тварини під місцевою епібульбарною анестезією 0,5 \% розчином алкаїну та ретробульбарною анестезією $2 \%$ розчином лідокаїну (1,0 мл). Трепаном діаметром 7 мм у верхній половині рогівки наносили концентричну епітеліальну насічку, в межах якої одноразовим офртальмологічним скальпелем видаляли епітелій разом із переднім шаром строми рогівки (викроювали клапоть товщиною до 0,2 мм). Контроль за відтворенням ерозії здійснювали методом фрарбування рогівки 0,5 \% розчином фрлуоресцеїну. Забір крові в різні терміни спостереження проводили з вушної вени зовнішнього краю вуха кролів.

Для дослідження особливостей вільнорадикального окиснення при експериментальній механічній непроникній травмі ока спектрофотометрично в крові визначали: концентрацію гідропероксидів (ГП) - методом, принцип якого полягає в осадженні протеїну трихлороцтовою кислотою з подальшим внесенням у середовище тіоціанату амонію [12]; вміст ТБК-реактантів (ТБК-АП) - при 532 нм за реакцією між малоновим діальдегідом і тіобарбітуровою кислотою 3 утворенням забарвленого триметинового комп- лексу [13]; ступінь окиснювальної модифікації білків (ОМБ) у плазмі крові - за рівнем альдегідо- та кетонопохідних динітрофренілгідразонів нейтрального характеру (АКДНФГ НХ) (ЕЗ70 нм), а також основного характеру (АКДНФГ ОХ) (Е430 нм) за методом О. Є. Дубініної і співавт. (1995) у модифрікації I. Ф. Мещишена (1998) [14]; рівень метаболітів нітрогену монооксиду $\left(\mathrm{NO}_{x}\right)$ в сироватці крові - шляхом реєстрації кінцевих стабільних метаболітів нітрогену монооксиду (нітритів/нітратів) після їх відновлення губчатим кадмієм у реакції Гріса [15].

Статистичну обробку результатів дослідження проводили загальноприйнятими методами варіаційної статистики з використанням програм Microsoft Excel i STATISTICA6.0 ("Statsoft", США). Для перевірки на відповідність вибірок даних нормальному закону розподілу було застосовано розрахунок критерію Шапіро-Уїлка. У зв'язку з відсутністю відповідності даних нормальному розподілу на рівні значущості $p<0,05$, рівень статистичної значущості відмінностей вибірок оцінювали за допомогою непараметричного критерію Манна-Уітні. Відмінності вважали статистично значущими при досягнутому рівні $p<0,05$.

РЕЗУЛЬТАТИ Й ОБГОВОРЕННЯ. ВСТаНОВлено підвищення вмісту продуктів білкової і ліпідної пероксидації в крові кролів за умови механічної непроникної травми рогівки. Так, вміст ГП достовірно зріс через 3 доби на 17,7 \%, через 7 діб - на 15,4 \%, через 10 діб - на 37,7 \% і через 14 діб - на 61,9 \% порівняно 3 контрольною групою $(p<0,05)$. Слід зазначити, що показник ГП у крові тварин 1-ї і 2-ї дослідних груп практично не відрізнявся, тоді як у 3-й групі він був достовірно більший (на 19,3 \%) від даних 2-ї групи, а в 4-й групі перевищував значення 3-ї групи на $17,5 \%$ (р<0,01) (табл.).

Вміст ТБК-АП у тварин дослідних груп також був вищий від значень контрольної групи. Аналізуючи динаміку змін цього показника протягом 14 діб, ми встановили хвилеподібні його зміни. Так, на 3 добу вміст ТБК-АП збільшився на 35,7 \% стосовно контролю, далі на 7 добу зменшився на 6,4 \% порівняно з 3 добою $з$ наступним зростанням на 10 і 14 доби, відповідно, на 9,8 та 5,0 \% відносно даних 2-ї і 3-ї дослідних груп $($ р $<0,05)$ (табл.).

Механічна непроникна травма рогівки у кролів супроводжувалася зростанням показників ОМБ. Так, рівень АКДНФГ НХ достовірно підвищився: через 3 доби - на 33,1 \%, через 7 діб - на 20,5 \%, через 10 діб - на 38,1 \% і через 14 діб на 51,9 \% порівняно 3 контрольною групою $(p<0,05)$. Слід зазначити, що показник АҚДНФГ НХ 
Таблиця - Показники пероксидного окиснення у крові кролів за умови механічної непроникної травми рогівки (Me [Q25-Q75])

\begin{tabular}{|c|c|c|c|c|c|}
\hline \multirow{3}{*}{ Показник } & \multicolumn{5}{|c|}{ Групи } \\
\hline & \multirow{2}{*}{$\begin{array}{c}\text { контрольна } \\
(n=6)\end{array}$} & \multicolumn{4}{|c|}{ дослідні } \\
\hline & & 1-ша $(n=18)$ & 2-га (n=14) & 3-тя $(n=10)$ & 4-та $(n=6)$ \\
\hline $\begin{array}{l}\text { ГП, ум. од./мг } \\
\text { білка }\end{array}$ & $0,82[0,74 ; 0,90]$ & $0,96^{\star}[0,89 ; 1,01]$ & $0,95^{\star}[0,86 ; 0,98]$ & $\begin{array}{c}1,14^{*}[1,06 ; 1,18] \\
\mathrm{p}_{2}<0,01\end{array}$ & $\begin{array}{c}1,33^{*}[1,23 ; 1,40] \\
p_{3}<0,01\end{array}$ \\
\hline $\begin{array}{l}\text { ТБК-АП, } \\
\text { кмоль/л }\end{array}$ & $5,78[5,68 ; 5,89]$ & $7,88^{\star}[7,80 ; 7,92]$ & $\begin{array}{c}7,34^{*}[7,31 ; 7,40] \\
p_{1}<0,01\end{array}$ & $\begin{array}{c}8,07^{*}[7,98 ; 8,14] \\
\mathrm{p}_{2}<0,01\end{array}$ & $\begin{array}{c}8,48^{*}[8,40 ; 8,54] \\
p_{3}<0,01\end{array}$ \\
\hline $\begin{array}{l}\text { АКДНФГ НХ, } \\
\text { опт. од./Г протеїну }\end{array}$ & $2,97[2,80 ; 3,18]$ & $4,05^{\star}[3,94 ; 4,14]$ & $\begin{array}{c}3,73^{*}[3,32 ; 3,92] \\
p_{1}<0,05\end{array}$ & $\begin{array}{c}4,14^{*}[4,05 ; 4,42] \\
\mathrm{p}_{2}<0,01\end{array}$ & $\begin{array}{c}4,52^{*}[4,51 ; 4,66] \\
p_{3}<0,001\end{array}$ \\
\hline $\begin{array}{l}\text { АКДНФГ ОХ, } \\
\text { опт. од./г протеїну }\end{array}$ & $1,05[0,98 ; 1,14]$ & $1,46^{\star}[1,35 ; 1,56]$ & $\begin{array}{c}1,36^{*}[1,21 ; 1,59] \\
\mathrm{p}_{1}<0,05 \\
\end{array}$ & $\begin{array}{c}2,07^{*}[1,96 ; 2,14] \\
p_{2}<0,001\end{array}$ & $\begin{array}{c}2,51 *[2,41 ; 2,52] \\
p_{3}<0,01\end{array}$ \\
\hline
\end{tabular}

Примітки:

1. * - різниця достовірна між контрольною і дослідними групами.

2. $\mathrm{p}_{1}$ - різниця достовірна між 1-ю і 2-ю групами.

3. $\mathrm{p}_{2}$ - різниця достовірна між 2-ю і 3-ю групами.

4. $\mathrm{p}_{3}$ - різниця достовірна між 3-ю і 4-ю групами.

у крові тварин 2-ї дослідної групи був достовірно нижчий (на 9,5 \%) від даних 1-ї групи, тоді як у 3-й групі він був вірогідно більший (на 14,7\%) від даних 2-ї групи, а в 4-й групі перевищував значення 3-ї групи на 9,9 \% $(p<0,01)$. Відмітимо, що динаміка змін вмісту АКДНФГ ОХ мала подібний характер (табл.).

В основі всіх сучасних концепцій розвитку різних захворювань лежить порушення структури клітинної мембрани, одним з фракторів ушкодження якої $є$ пероксидне окиснення. Дослідники вивчили роль вільнорадикальних процесів у розвитку ряду офтальмологічних патологій і встановили, що оксидативний стрес $€$ однією 3 причин розвитку та прогресування таких захворювань, як катаракта, глаукома, діабетична ретинопатія $[16,17]$. При механічній травмі активація пероксидного окиснення білків і ліпідів сприяє розвитку оксидативного стресу, який, за даними різних авторів, проявляється ушкодженням біологічних структур клітин, порушенням третинної структури білків, унаслідок чого знижується їх фуннкціональна активність [18].

При ряді очних захворювань нітроген монооксид відіграє важливу роль в ушкодженні клітинних структур ока [11]. Результати нашого дослідження свідчать про хвилеподібну динаміку змін кінцевих продуктів нітрогену монооксиду в сироватці крові кролів при механічній непроникній травмі рогівки. Так, на 3 і 7 доби концентрація $\mathrm{NO}_{x}$ була менша від контрольних значень у середньому на 26,0 \% з наступним збільшенням на 10 і 14 доби, відповідно, на 8,0 та 24,9\% відносно контрольної групи $(p<0,01)$ (рис.).

Отримані дані щодо зниження рівня в сироватці крові метаболітів нітрогену монооксиду в ранній посттравматичний період в експериментальних тварин збігаються з результатами дослідження М. В. Турчина і співавт. та тракту-

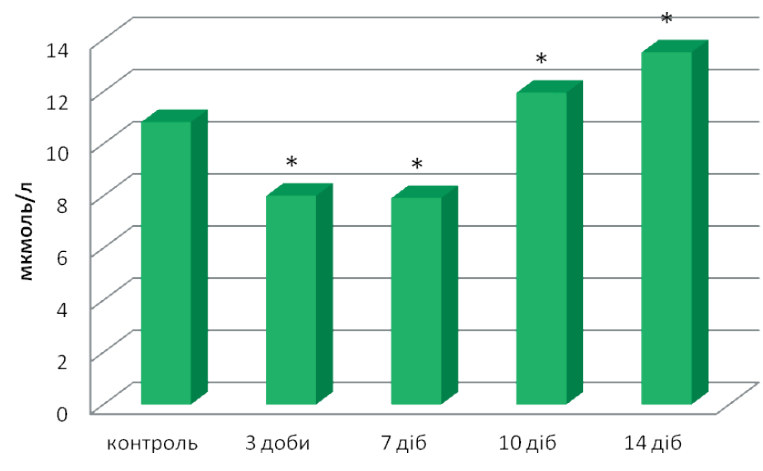

Рис. Динаміка зміни метаболітів нітрогену монооксиду в сироватці крові кролів за умови експериментальної непроникної механічної травми ока (* - різниця достовірна між контрольною і дослідними групами).

ються як один із компонентів неспецифічного захисту організму [11]. Проте результати, які ми отримали, вказують на розвиток нітрооксидативного стресу з 10 доби поруч з оксидативним стресом, що проявляється однонаправленими змінами ТБК-АП, ОМБ та $\mathrm{NO}_{x}$ у бік зростання в крові тварин 3-ї і 4-ї дослідних груп.

ВИСНОВКИ. 1. За умови експериментальної непроникної травми рогівки спостерігають достовірне зростання у крові показників пероксидного окиснення ліпідів (підвищення рівнів гідропероксидів і ТБК-активних продуктів) та окиснювальної модифрікації білків (альдегідо- і кетонопохідних динітрофенілгідразонів нейтрального й основного характеру) стосовно контролю з мінімальними значеннями на 7 добу та максимальними - на 14 добу $(p<0,05)$.

2. Експериментальна непроникна травма рогівки супроводжується зниженням рівня кінцевих продуктів нітрогену монооксиду на 3-7 доби в середньому на 26,0 \% 3 наступним зростанням на 10 і 14 доби, відповідно, на 8,0 та 24,9 \% відносно контрольної групи $(p<0,01)$. 
Перспективи подальших досліджень. Буде досліджено стан антиоксидантної системи захисту в різні періоди експериментальної не- проникної травми рогівки для більш глибокого патогенетичого обґрунтування механізмів розвитку оксидативного стресу.

\section{СПИСОК ЛІТЕРАТУРИ}

1. Patel Daksha. Eye injuries: improving our practice / Daksha Patel // Community Eye Health Journal. - 2015. 28, Issue 91. - P. 41-42.

2. Squissato V. Get out of a scrape! An approach to corneal foreign bodies and abrasions for the primary care physician / V. Squissato, G. Brown, S. Baxter // Occup. Med. Health Aff 3. - 2015. - P. 202. - doi:10.4172/23296879.1000202

3. Bhogal G. Penetrating ocular injuries in the home / G. Bhogal, P. J. Tomlins, P. I. Murray // J. Public Health. 2007. - 29. - P. 72-74

4. Чуднявцева Н. А. Восстановительное лечение больных с травмами глаза, осложненными иридодиализом / Н. А. Чуднявцева, Ю. Н. Родина, С. Е. Чуднявцев // Офтальмол. журн. - 2010. - № 1. - С. 102-105.

5 . Work related eye injuries treated in hospital emergency departments in the US / H. Xiang, L. Stallones, G. Chen, G. A. Smith // Am. J. Ind. Med. - 2005. No. 48. - P. 57-62.

6. A case-crossover study on transient risk factors of work-related eye injuries / S. Y. Chen, P. C. Fong, S. F. Lin // Occup. Environ. Med. - 2009. - No. 66. P. 517-522.

7. Harris P. M. Nonfatal occupational injuries involving the eyes, 2004 / P. M. Harris // US Bureau of Labor Statistics. - 2006. - P. 1-7.

8. Epidemiologic study on work-related eye injuries in Kaohsiung / C. K. Ho, Y. L. Yen, C. H. Chang [et al.] // Taiwan. Kaohsiung J. Med. Sci. - 2007. - No. 23. P. 463-469.

9. Регеда М. С. Роль порушень перекисного окиснення ліпідів та активності ферментів антиоксидантного захисту в трахеї морських свинок у патогенезі експериментального алергічного альвеоліту та їх корекція тіотріазоліном / М. С. Регеда, М.Л.Байда // Експерим. та клініч. фрізіологія та біохімія. - 2013. № 1. - C. 47-51.

\section{REFERENCES}

1. Patel Daksha (2015). Eye injuries: improving our practice. Community Eye Health Journal, 28 (91), 41-42.

2. Squissato, V., Brown, G., \& Baxter, S. (2015). Get out of a scrape! An approach to corneal foreign bodies and abrasions for the primary care physician. Occup. Med. Health Aff., 3, 202. doi:10.4172/2329-6879.1000202

3. Bhogal, G., Tomlins, P. J., \& Murray, P. I. (2007). Penetrating ocular injuries in the home. J. Public Health, 29, 72-74.
10. Беський В. О. Показники вільнорадикального окиснення крові та бронхоальвеолярного лаважу при синдромі гострого ушкодження легень /В.О.Беський, Л. А. Грищук, М. І. Марущак // Суч. мед. технології. 2014. - № 2. - C. 48-54.

11. Турчин М. В. Особливості процесів вільнорадикального окиснення крові та водянистої вологи за умов експериментальної механічної непроникаючої травми рогівки / М. В. Турчин, І. М. Кліщ // Вісн. наук. дослідж. - 2014. - № 4. - С. 103-107.

12. Лабораторні методи досліджень у біології, тваринництві та ветеринарній медицині / [В.В.Влізло, Р. С. Федорук, І. Б. Ратич та ін.] ; за ред. В.В.Влізла. л. : СПОЛОМ, 2012. - 756 с.

13. Федорова Т. Н. Реакции с тиобарбитуровой кислотой для определения малонового диальдегида крови методом флюориметрии / Т. Н. Федорова, Т. С. Коршунова, Э. Г. Ларский // Лаб. дело. - 1983. № 3. - C. 25-28.

14. Мещишен І. Ф. Метод визначення окиснювальної модифрікації білків плазми (сироватки) крові / І. Ф. Мещишен // Бук. мед. вісн. - 1998. - 2, № 1. C. $156-158$.

15. Емченко Н. Л. Универсальный метод определения нитратов в биосредах организма / Н. Л. Емченко, О.И.Цыганенко, Т. В. Ковалевская // Клинич. лаб. диагностика. - 1994. - № 6. - С. 19-20.

16. Oshida E. Free radicals in the aqueous humor of patients with glaucoma / E. Oshida, Y. Matsumoto, K. Arai // Clinical Ophthalmology. - 2010. -4. - P. 653660.

17. Vinson J. A. Oxidative stress in cataracts / J. A. Vinson // Pathophysiology. - 2006. - 13. - P. 151-162.

18. Дікал М. В. Окиснювальна модифікація білків у печінці щурів за умов уведення 2,4-динітрофенолу / М.В.Дікал // Клініч. та експерим. патологія. - 2013. XII, № 2 (44). - C. 71-73.

4. Chudnyavtseva, N.A. (2010). Vosstanovitelnoye lecheniye bolnykh s travmami glaza, oslozhnennymi iridodializom [Restorative treatment of patients with eye injuries complicated by iridodialysis]. Oftalmologicheskiy zhurnal - Ophthalmological Journal, 1, 102-105 [in Russian].

5. Xiang, H., Stallones, L., Chen, G., \& Smith, G.A. (2005). Work related eye injuries treated in hospital emergency departments in the US. Am. J. Ind. Med., 48, 57-62. 
6. Chen, S.Y., Fong, P.C., Lin, S.F., Chang, C.H., \& Chan, C.C. (2009). A case-crossover study on transient risk factors of work-related eye injuries. Occup. Environ. Med., 66, 517-522.

7. Harris, P.M. (2006). Nonfatal occupational injuries involving the eye, 2004. US Bureau of Labor Statistics, 1-7.

8. Ho, C.K., Yen, Y.L., Chang, C.H., Chiang, H.C., Shen, Y.Y., et al. (2007). Epidemiologic study on workrelated eye injuries in Kaohsiung, Taiwan. Kaohsiung J. Med. Sci., 23, 463-469.

9. Reheda, M.S., \& Baida, M.L. (2013). Rol porushen perekysnoho okysnennia lipidiv ta aktyvnosti fermentiv antyoksydantnoho zakhystu $v$ trakhei morskykh svynok u patohenezi eksperymentalnoho alerhichnoho alveolitu ta yikh korektsiia tiotriazolinom [Role of violations of lipid peroxidation and activity of antioxidant enzymes in the guinea pig trachea in the pathogenesis of experimental allergic alveolitis and their correction by thiotriazolinum]. Eksperymentalna ta klinichna fiziolohiia ta biokhimiia Experimental and Clinical Physiology and Biochemistry, 1, 47-51 [in Ukrainian].

10. Beskyi, V.O., Hryshchuk, L.A., \& Marushchak, M.I. (2014). Pokaznyky vilnoradykalnoho okysnennia krovi ta bronkhoalveoliarnoho lavazhu pry syndromi hostroho ushkodzhennia lehen [Indicators of free radical oxidation of blood and bronchoalveolar lavage with acute lung injury syndrome]. Suchasni medychni tekhnolohii - Modern Medical Technology, 2, 48-54 [in Ukrainian].

11. Turchyn, M.V., \& Klishch, I.M. (2014). Osoblyvosti protsesiv vilnoradykalnoho okysnennia krovi ta vodianystoi volohy za umov eksperymentalnoi mekhanichnoi nepronykaiuchoi travmy rohivky [Features of processes of free radical oxidation of blood and aqueous humor under the conditions of experimental mechanical nonpenetrating corneal trauma]. Visnyk naukovykh dosli- dzhen - Bulletin of Scientific Researches, 4, 103-107 [in Ukrainian].

12. Vlizlo, V.V., Fedoruk, R.S., \& Ratych, I.B. (2012). Laboratorni metody doslidzhen u biolohii, tvarynnytstvi ta veterynarnii medytsyni [Laboratory methods of research in biology, livestock and veterinary medicine]. Lviv: SPOLOM [in Ukrainian].

13. Fedorova, T.N., Korshunova, T.S., \& Larskiy, E.G. (1983). Reaktsii s tiobarbiturovoy kislotoy dlya opredeleniya malonovogo dialdegida krovi metodom fluorimetrii [Reactions with thiobarbituric acid for the determination of malonic dialdehyde by fluorometry]. Laboratornoe delo - Laboratory Work, 3, 25-28 [in Russian].

14. Meshchyshen, I.F. (1998). Metod vyznachennia okysniuvalnoi modyfikatsii bilkiv plazmy (syrovatky) krovi [Method of determination of oxidative modification of plasma proteins (serum)]. Bukovynskyi medychnyi visnyk - Bukovyna Medical Bulletin, 2, 1, 156-158 [in Ukrainian].

15. Emchenko, N.L., Tsyganenko, O.I., \& Kovalevskaya, T.V. (1994). Universalnyiy metod opredeleniya nitratov $\mathrm{v}$ biosredakh organizma [A universal method for the determination of nitrates in the body's biomass]. Klinicheskaya laboratornaya diagnostika - Clinical Laboratory Diagnostics, 6, 19-20 [in Russian].

16. Oshida, E., Matsumoto, E., \& Arai, K. (2010). Free radicals in the aqueous humor of patients with glaucoma. Clinical Ophthalmology, 4, 653-660.

17. Vinson, J.A. (2006). Oxidative stress in cataracts. Pathophysiology, 13, 151-162.

18. Dikal, M.V. (2013). Okysniuvalna modyfikatsiia bilkiv u pechintsi shchuriv za umov uvedennia 2,4-dynitrofenolu [Oxidation modification of proteins in the liver of rats under the conditions of 2,4-dinitrophenol]. Klinichna ta eksperymentalna patolohiia - Clinical and Experimental Pathology, XII, 2(44), 71-73 [in Ukrainian].

\section{ОСОБЕННОСТИ ОКИСЛИТЕЛЬНЫХ ПРОЦЕССОВ ПРИ ЭКСПЕРИМЕНТАЛЬНОЙ МЕХАНИЧЕСКОЙ НЕПРОНИКАЮЩЕЙ ТРАВМЕ РОГОВИЦЫ}

\section{Резюме}

Вступление. Дезорганизация процессов перекисного окисления имеет важное значение в патогенезе механической непроникающей травмы роговицы, однако эти взаимосвязи изучены недостаточно, что побудило нас провести исследования собственно такого направления.

Цель исследования - изучить изменения интенсивности перекисного окисления липидов, белков и содержание метаболитов оксида азота в крови кроликов в условиях механической непроникающей травмы роговицы в динамике.

Методы исследования. Экспериментальные исследования проводили на половозрелых кроликах породы "Шиншилла". Для изучения особенностей свободнорадикального окисления при экспериментальной механической непроникающей травме глаза спектрофотометрически в крови определяли концентрацию гидроперекисей, содержание ТБК-реактантов, степень окислительной модификации белков, уровень метаболитов оксида азота. 
Результаты и обсуждение. Установлено повышение содержания продуктов белковой и липидной пероксидации в крови кроликов при механической непроникающей травме роговицы. Результаты нашего исследования свидетельствуют о волнообразной динамике изменений конечных продуктов оксида азота в сыворотке крови животных при механической непроникающей травме роговицы.

Выводы. При экспериментальной непроникающей травме роговицы наблюдают достоверный рост в крови показателей перекисного окисления липидов (повышение уровней гидроперекисей и ТБК-активных продуктов) и окислительной модификации белков (альдегидо- и кетонопроизводных динитрофенилгидразонов нейтрального и основного характера) относительно контроля с минимальными значениями на 7 сутки и максимальными - на 14 сутки $(p<0,05)$. Экспериментальная непроникающая травма роговицы сопровождается снижением уровня конечных продуктов оксида азота на 3-7 сутки в среднем на 26,0 \% с последующим ростом на 10 и 14 сутки, соответственно, на 8,0 и 24,9 \% относительно контрольной группы $(p<0,01)$.

КЛЮЧЕВЫЕ СЛОВА: травма роговицы; оксислительный стресс; динамика; эксперимент.

\title{
PECULIARITIES OF OXIDATIVE PROCESSES AT EXPERIMENTAL NONPENETRATING MECHANICAL CORNEAL TRAUMA INJURY
}

\begin{abstract}
Summary
Introduction. Disorganization of peroxidation processes plays an important role in the pathogenesis of a mechanical nonpenetrating corneal injury [11], but these interrelationships were not been studied sufficiently, which led us to study the proper direction of this.

The aim of the study - to investigate the changes in the intensity of peroxide oxidation of lipids, proteins, and the content of nitrogen monooxide metabolites in rabbit blood under conditions of mechanical nonpenetrating corneal
\end{abstract} injury in dynamics.

Materials and Methods. Experimental studies were carried out on mature rabbits of the Chinchilla breed. For the study of the features of free radical oxidation at experimental mechanical nonpenetrating eye injury spectrophotometrically, the concentration of hydroperoxides, the content of TBA-reactants, degree of oxidative modification of proteins, level of metabolites of nitrogen monoxide were determined.

Results and Discussion. It was established the increase in the content of proteins and lipid peroxidation products in rabbits during the mechanical nonpenetrating corneal injury. The results of our study indicate a wave-like dynamics of changes in end products of nitrogen monoxide in serum of rabbits with mechanical non-penetrating corneal injury.

Conclusions. Under the condition of an experimental non-penetrating corneal injury, there is a significant increase of lipid peroxidation (increased levels of hydroperoxides and TBA-active products) and oxidation modification of proteins (aldehyde- and ketone derivatives of dinitrophenylhydrazones of neutral and basic nature), compare to control, with minimum values by 7 days and maximum - by 14 days $(p<0.05)$. Experimental non-penetrating corneal injury is accompanied by a decrease in the level of end products of nitrogen monoxide by 3-7 days on average by $26.0 \%$, followed by an increase of 10 and 14 days, respectively, by $8.0 \%$ and $24.9 \%$, relative to the control group $(p<0.01)$.

KEY WORDS: corneal injury; oxidative stress; dynamics; experiment.

Отримано 02.08.18

Адреса для листування: І. М. Кліщ, Тернопільський державний медичний університет імені І. Я. Горбачевського, майдан Волі, 1, Тернопіль, 46001, Україна, e-mail: klishch@tdmu.edu.ua. 